\title{
LOCKE AND BAYLE ON RELIGIOUS TOLERATION
}

\author{
Marlies Galenkamp*
}

\begin{abstract}
In Western-European societies, two questions are currently at the centre of political debate. What is the scope and what are the limits of religious toleration? What is the proper role of the state with regard to religious issues? By addressing these two topics, Dutch constitutional law scholars commonly start from two presumptions. First of all, the presumption in favour of liberty (leading to a quite absolute interpretation of fundamental rights) and secondly, the doctrine of interpretative restraint by civil authorities with regard to religious matters. These presumptions are generally considered as uncontested axioms. It seems to me that both presumptions may be qualified, however. This will be done by elaborating on the views of two $17^{\text {th }}$-century scholars on religious toleration, the Englishman John Locke and the Frenchman Pierre Bayle. Interestingly, both formulated their insights during their exile in the Dutch Republic. It will turn out that the dominant interpretation of the presumptions rests on a too superficial reading of Locke and on a disregard of Bayle's insights, respectively.
\end{abstract}

Keywords: Religious toleration; limits of toleration; constitutional rights; reciprocity; John Locke; Pierre Bayle.

\section{Introduction}

In the Netherlands, but also in other Western-European societies, religions are currently more visible than ever. One's religious identity seems to play a key role in identification processes. This tendency is often accompanied by the urge for the recognition of one's religious identity by the state. Mostly, this is done by resorting to constitutional rights such as the freedom of religion and of conscience. Take, for example, the classic discussion on the SGP - a Dutch Orthodox-Christian political party - and its view that women should not be eligible for political office, recurring debates on conscientious objections to same-sex marriages by civil servants and the recently dismissed bill on the ban of ritual slaughtering by Jews and Muslims. In all these topical debates, constitutional rights - to freedom of religion and of conscience - were invoked.

In order to provide a solution to these issues, constitutional jurists generally refer to two presumptions in the Dutch doctrine of fundamental rights. The first one might be summarised as the presumption in favour of liberty, leading to a rather extensive and absolute interpretation of those rights. Secondly, there is the doctrine of interpretative restraint by the state and civil authorities with regard to religious matters. These presumptions are generally considered as uncontested axioms. It seems to me that both may be qualified, however. In my contribution to this special issue, I will do this by elaborating on the views of two $17^{\text {th }}$-century scholars on religious toleration, the Englishman John Locke and the Frenchman Pierre Bayle. Both formulated their insights during their exile in the Dutch Republic. I believe that the currently dominant interpretation of the two presumptions rests on a too superficial reading of Locke and on a disregard of Bayle's insights, respectively.

At the moment, both Locke and Bayle are at the centre of philosophical and historical debate. This is mainly due to the monumental work on the Enlightenment by the British scholar of Dutch history, Jonathan Israel. ${ }^{1}$ He distinguishes a Radical Enlightenment

\footnotetext{
Associate Professor in Legal Philosophy, Erasmus School of Law, Erasmus University Rotterdam, The Netherlands. E-mail: Galenkamp@law.eur.nl.

J.I. Israel, The Dutch Republic (1995); 'The Intellectual Debate about Toleration in the Dutch Republic', in C. Berkvens-Stevelinck, J.I. Israel and G.H.M. Posthumus Meyjes (eds.), The Emergence of Tolerance in the Dutch Republic (1997), at 18-25; Locke, Spinoza and the Philosophical Debate Concerning Toleration in the Early Enlightenment (1670-1750), Part 62, no. 6 (1999); Radical Enlightenment. Philosophy and the Making of Modernity 1650-1750 (2001); Bayle, the Enlightenment and Modern Western Society (Pierre
} 
(exemplified by Bayle) and Moderate Enlightenment (Locke's position). Israel ardently defends the radicalism of Bayle, while he attacks the moderation of Locke. I will take Israel's model as my starting point, but I will develop a critical perspective on it. In my opinion, both Locke's and Bayle's views on religious toleration may not only have their merits, but also their shortcomings.

My exposé will be set up as follows. Firstly, Israel's theory of Enlightenment will be summed up. Hereafter, I will elaborate on the two fundamentals of the Dutch doctrine of constitutional rights. In the next two sections Locke's and Bayle's insights on the topic of religious toleration will be expounded. After a sketch of the historical context I will zoom in on two questions. Firstly, what is the scope and what are the limits of religious toleration? Secondly, what is the proper role of the state with regard to religious issues? In the last section, I will first assess Israel's stance on the two positions. Then, I will investigate how to translate the insights gained from Locke and Bayle to the current debate on constitutional rights: What lessons may be drawn?

\section{Israel's Enlightenment Thesis}

To start with, it is by no means self-evident to compare our current debates on religious topics with those of the $17^{\text {th }}$ century. At first sight, the contexts are too divergent to admit of an easy comparison. The main reason for this is the overwhelming presence of religions in early modern times and the quite marginal role religion takes in current debates. Nowadays, the tensions between religions are negligible in comparison with the omnipresent and enduring religious wars in early modern Western Europe. That is not to say that there are no similarities. The main similarity is that both then and now religions have become problematic. They are not taken for granted any longer. Owing to the diversification of Western-European societies (as a result of Reformation tendencies and the influx of new religions such as Islam) novel and quite parallel questions arise. How to cope with and accommodate religious plurality? Are there limits to religious toleration, and if so, where are these limits? What is the proper role of the state with regard to religious matters?

In view of this similarity, it is not surprising that a considerable number of historians have reverted to the early modernity - and specifically to the $17^{\text {th }}$-century Dutch Republic - as the breeding ground of modern and liberal ideals. Take, for example, the historical-philosophical research undertaken by Simon Schama ${ }^{2}$ or the NWO research program, The Early Enlightenment in the Dutch Republic, directed by W. van Bunge at the Philosophy Department of the Erasmus University Rotterdam. ${ }^{3}$ One of the most influential researchers at the moment, however, is Jonathan Israel. Over the last decades he has brought out an impressive - with regard to both the amount and size - set of publications on the Enlightenment. In his work, Israel convincingly counters the commonplace that studying history of philosophy is a stuffy affair, far away from the hustle and bustle of actual debates. He demonstrates that in order to understand topical debates we cannot but return to their historical underpinnings. What are his main insights on Enlightenment? They may be summed up in three postulates.

The first postulate concerns the importance of the Enlightenment, hereby countering postmodern critics targeting the Enlightenment's universalism and rationalism as too abstract and its humanism as naive. According to Israel, the Enlightenment - that took place in Western Europe from 1680 to 1800 - should be seen as the most important

Bayle Lecture) (2005); Enlightenment Contested. Philosophy, Modernity and the Emancipation of Men, 1670-1752 (2006); Gedachtevrijheid versus godsdienstvrijheid. Een dilemma van de Verlichting (2007); 'Bayle's Double Image during the Enlightenment', in W. van Bunge and H. Bots (eds.), Pierre Bayle (1647-1706), Le philosophe de Rotterdam: Philosophy, Religion and Reception (2008), at 135-152; A Revolution of the Mind. Radical Enlightenment and the Intellectual Origins of Modern Democracy (2010) and Democratic Enlightenment. Philosophy, Revolution and Human Rights 1750-1790 (2011).

2 See, e.g. Schama's Huizinga-lecture, 'What Happened to the Idea of Toleration?', 9 December 2011, Leiden, published in abbreviated form in NRC Handelsblad, 10 December 2011.

3 W. van Bunge et al., The Dictionary on Seventeenth and Eighteenth Century Dutch Philosophy, Part I and II (2003) and W. van Bunge, De Nederlandse Republiek, Spinoza en de radicale verlichting (2010). 
and profound intellectual, social and cultural transformation or even 'amelioration' of the Western world and the most formative in shaping modernity. It lies at the basis of modern ideals such as rule of law, individual liberties and freedoms, limited and liberal government, separation of church and state, democracy, toleration and racial and sexual equality.

Secondly, to Israel the Enlightenment should not be seen as a uniform movement. Two schools can be distinguished: the Radical and the Moderate Enlightenment. As Israel notes, there is a 'deep philosophical rift' ${ }^{4}$ between them. The two currents diverged over every fundamental issue. As we shall see in Sections 4 and 5, they also differed on the topic of religious toleration. Chronologically, the Enlightenment movement started as quite a radical one. This radicalism can be discerned in the works of Bayle and Spinoza. It was raised in opposition to mainstream thinking and it clashed with former religious traditions and beliefs. Predominant in this current is the right of every individual to reject and overthrow all structures of theological tradition, hierarchy and authority. Radical Enlightenment scholars were driven by the urge to weaken the power of the clergy and strengthen the state for the good of society. In this current a key role was played by the secular state. Moreover, radical philosophers set up a distinction between morals and religion. Morals should not be determined by religious authorities, but should be based on reason alone.

Especially after the 1790s, the Moderate Enlightenment gained more and more ground in Western Europe. Instead of a revolution this movement aimed at a reform and repair of traditional institutions on the basis of reason. So moderate thinkers tried to reconcile new premises - for example on natural rights of individuals, on political power legitimised by the consent of the governed and on limited government - with reaffirming old ones: the everlasting need for religious authority, tradition and natural law maxims. In this current, the focus was on the individual freedom of religion and of conscience. The assumption seemed to be that if this condition was met, the state could play a limited role with regard to religious matters. As we shall see in Section 4, a paradigmatic - although quite early - example of this compromised version of Enlightenment was Locke's political theory. In it one can discern, in the words of Israel, 'a withdrawal, or retreat, of the state from the theological and ecclesiastical sphere once the liberty and autonomy of a plurality of churches is acknowledged'.

Finally, Israel's view of Enlightenment is characterised by a passionate or even idolatrous plea for a rehabilitation of the Radical current. According to him, this is not only the more consistent theoretical position, but also the more realistic one in offering solutions to both $17^{\text {th }}$ and $21^{\text {st }}$ century problems. Besides, to him it is exactly this tradition that lies at the basis of modern egalitarian and democratic values. Moderate thinkers such as Hume or Locke can be blamed for having watered down the intellectual achievements of the radical thinkers by making too many compromises. ${ }^{6}$

It seems to me that Israel's analysis offers a useful starting point for my own research, although I do not see it as the final word on the matter. As I shall argue in Section 6, his stance to me seems too one-sided and ideological to be convincing. I do not subscribe to Israel's postulate that the Radical Enlightenment is the more convincing and useful position for current debates on religious toleration. It seems to me that both the Radical and the Moderate Enlightenment - represented by Bayle and Locke, respectively - may have their merits.

\section{Two Fundamentals of the Dutch Doctrine on Constitutional Rights}

But let us now first elaborate on two fundamentals of the Dutch doctrine on constitutional rights and more specifically on the freedom of religion and of conscience. These are (1) the extensive and absolute interpretation of these rights and (2) the doctrine of interpretative restraint by state and civil authorities.

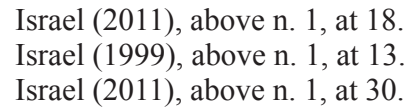


First, liberal-democratic states are generally based on the primacy of the autonomous individual and his rights. Within liberal-democratic states, there seems to be - in the words of Joel Feinberg - 'a presumption in favour of liberty'. ${ }^{7}$ The father of liberalism, John Stuart Mill, already argued in the $19^{\text {th }}$ century that 'the burden of proof is supposed to be with those who are against liberty, who contend for any restriction or prohibition. ... The a priori presumption is in favour of freedom .... ${ }^{8}$ Hence, liberal argumentations always start from the assumption of freedom. There is no need at all for a justification of this presumption. Instead, the onus of justification is on civil authorities who would limit this freedom. Constitutional rights such as the right to freedom of religion and of conscience are commonly seen as the legal expressions of this axiomatic freedom. In view of this linkage, it is a small wonder that in Dutch constitutional legal circles one may often discern a rather extensive and absolute interpretation of those rights in general and of the right to freedom of religion and of conscience more specifically. ${ }^{9}$ Burkens' Dutch textbook on constitutional rights, one of the standard texts in this field, is exemplary: ${ }^{10}$

Actions by the authorities should always be limited and specific. Diametrically opposed to this, there is the freedom of the individual. The citizen is in relation to the authorities free to do what he likes. ... This freedom is guaranteed by the provision of constitutional rights. The way citizens make use of their fundamental rights is their own business.

A second fundamental of the Dutch doctrine of constitutional rights flows from the first one. Due to the axiomatic individual autonomy, the role of the state with regard to religious issues is commonly conceptualised in quite limited and passive terms. It is not the task of civil authorities (such as judges) to interfere with religious debates and to determine what would be the proper form of religious worship. By doing so, the state would breach the individual's autonomy impermissibly. Within the Dutch constitutional law setting, this consideration is commonly known as the doctrine of judicial restraint when it comes to the interpretation of religious practices by civil authorities. ${ }^{11}$ This doctrine also shows all the traits of an uncontested axiom. ${ }^{12}$ Insofar as civil authorities are assigned a role in this field, it is mostly argued that they should act as a positive facilitator of religions. ${ }^{13}$

In my opinion, these two fundamentals can be called into question by focusing on Locke's and Bayle's views. A rereading of Locke's work might put some question marks behind the axiomatic autonomy of the rights bearer. With the help of Bayle's theory, we can cast doubt on the currently dominant interpretation of the doctrine of interpretative restraint.

J. Feinberg, Harm to Others (1983); part I of the four-volume work on The Moral Limits of the Criminal Law, at 9.

J.S. Mill, 'On the Subjection of Women', in J.S. Mill and H.T. Mill, Essays on Sex Equality, edited and with an Introductory Essay by Alice S. Rossi (1869/1970), at 126-127.

9 See further on this topic M. Galenkamp, 'Towards a Socialization of Fundamental Rights', in E. Brems (ed.), Conflicts between Fundamental Rights (2008), at 149-165 and M. Galenkamp, 'Als de dienst het toelaat', in H. Broeksteeg and A. Terlouw (eds.), Overheid, recht en religie (2011a), at 283-298.

${ }_{10}$ (Translation by M. Galenkamp). M.C. Burkens, Algemene leerstukken van grondrechten naar Nederlands constitutioneel recht (2006), at 123.

11 B.P. Vermeulen, 'Artikel 6', in A.K. Koekkoek (ed.), De Grondwet. Een systematisch en artikelsgewijs commentaar (2000), at 96.

${ }_{12}$ M. Galenkamp, 'Religieuze overtuigingen en het discriminatieverbod. Enkele bedenkingen bij het leerstuk van interpretatieve terughoudendheid', Trema, mei, at 251-256 (2005).

${ }_{13}$ For example, T. Loenen, Geloof in het geding. Juridische grenzen van religieus pluralisme in het perspectief van de mensenrechten (2006), at 80 et seq.; M. de Blois, 'Two Cities in Conflict', in M.L.P. Loenen and J.E. Goldschmidt (eds.), Religious Pluralism and Human Rights in Europe: Where to Draw the Line? (2007), at 172; W. van der Burg, 'De rechterlijke macht en culturele en religieuze diversiteit', Nederlands Juristenblad, 17 September, at 2026-2031 (2010) and K. Henrard, The Ambiguous Relationship between Religious Minorities and Fundamental Minority Rights (2011). 


\section{John Locke (1632-1704)}

\subsection{Context}

In the field of Dutch constitutional law, John Locke is commonly viewed as a clear and univocal scholar with easily accessible viewpoints. He is the father of the idea of natural and inalienable rights of individuals, to be guaranteed by the state. In addition, he has provided the philosophical underpinnings of the rule of law, the idea that civil authorities are always bound by the law. This short summary, inspiring as it is due to its simplicity and elegance, is not the whole story, however. In this section, I will shed some light on some lesser known assumptions. This will be done by expounding Locke's view on religious toleration, its limits and the role of the state. Let me first sketch the context of his writings.

Locke was born in 1632, in the middle of the English Civil Wars. His work should be seen in the context of increasing absolutism in the 17th century and the enduring religious strife and intolerance, both in England (Stuart monarchy) and in other WesternEuropean states, such as France (Louis XIV). In 1683, in order to escape the fate of prison due to his revolutionary (Whig) activities against the absolutist and Catholic king James II, Locke seeks refuge in France and later on in Holland. In 1689, just after the Glorious Revolution - the overthrow of James II by the Dutch stadholder William III - Locke returns to England. During his exile in the Dutch Republic, he wrote his most famous works, Second Treatise of Government (1689a) ${ }^{14}$ and A Letter Concerning Toleration (1689b). ${ }^{15}$ Other works that are relevant to the topic under review are Locke's First Tract on Government (1660), ${ }^{16}$ Essays on the Law of Nature $(1664)^{17}$ and the Essay Concerning Toleration (1667). ${ }^{18}$

\subsection{Locke's Natural Law}

In order to grasp Locke's view on religious toleration and its limits, we cannot but start with one of the key concepts of Locke's doctrine, natural law. As we shall see below, natural law not only establishes limits to what an individual may do with his rights, but also paves the way for a considerable restriction of the scope of toleration.

Locke's view of the natural law can be found in his famous Second Treatise of Government. Here Locke presents his view of the social contract. According to him, the right to government is always based on the consent of the governed. In entering civil and political society, people give up their power to protect themselves and to punish offences against the natural law. They put that power into the hands of society (and at a later stage into the hands of state authorities). The chief end of this transfer is the preservation of life, liberty and estate, together: 'property'. As we all know, all classic social contract theories (Hobbes, Locke and Rousseau) start from a thought experiment, that is, a situation without a society, state and positive laws. This is called the state of nature. In Locke's view the state of nature is seen as a state of liberty, but it is not a state of licence. For even though the people in it are free, equal and independent, and hence are not bound by the will of others, they are still subject to the divinely ordained natural law that imposes limitations on their natural freedoms. We are obliged to obey God's will as expressed in the natural law. These God-given moral obligations are 'writ in the hearts of all mankind" ${ }^{19}$ and they can be grasped through the exercise of human reason.

14 J. Locke, Second Treatise of Government, edited and introduced by C.B. Macpherson (1689a/1980).

J. Locke, A Letter Concerning Toleration, edited and introduced by J.H. Tully (1689b/1983).

J. Locke, First Tract on Government, edited and introduced by P. Abrams (1660/1967), John Locke: Two Tracts on Government.

7 J. Locke, Essays on the Law of Nature, in W. von Leyden (1664/1954), John Locke: Essays in the Law of Nature.

18 J. Locke, Essay concerning Toleration (and other Writings on Law and Politics) (1667-1683), edited and introduced by J.R. Milton and P. Milton (1667/2006).

${ }_{19}$ Locke (1689a), above n. 14, at 21. 
As to the contents of natural law maxims, Locke writes:

The state of nature has a law of nature to govern it, which obliges every one: and reason, which is that law, teaches all mankind, who will but consult it, that being all equal and independent, no one ought to harm another in his life, health, liberty or possessions: for men being all the workmanship of one omnipotent, and infinitely wise maker; all the servants of one sovereign master, sent into the world by his order and about his business; they are his property, whose workmanship they are, made to last during his, not one another's pleasure. ${ }^{20}$

And further on in the text:

Every one, as he is bound to preserve himself ...; so by the like reason when his own preservation comes not in competition, ought he, as much as he can, to preserve the rest of mankind, and may not, unless it be to do justice on the offender, take away, or impair the life, or what tends to the preservation of the life, the liberty, health, limb, or goods of another. ${ }^{21}$

These natural law maxims apply not only in the state of nature, but also in civil society. It will be clear by now that these moral maxims establish limits to what an individual may do with his natural rights. For example, if someone should appropriate more than he may use under the pretext of his property right, he would offend against the natural law. According to Locke, we have a moral duty to leave enough and as good for others. This is a duty towards others, but ultimately it rests upon our duty towards God.

\subsection{Locke on Toleration}

In this section, we will focus on Locke's view of toleration as it developed over time. The Locke we have come to know - the father of natural rights and of religious toleration - was preceded by a less-known Locke who was wary of providing too much religious liberty to citizens.

In his 1660 First Tract on Government, Locke is still an opponent of religious toleration. Here, the emphasis is on the state's duty to provide order. No doubt, this view should be seen in the context of the civil and religious wars in England of the time. The civil magistrate may lawfully impose limits on the forms of religious worship in case this would contribute to the good of society. In this text, Locke is quite sensitive to the danger of rights abuse: 'Grant the people once free and unlimited exercise of their religion and where will they stop ... ? Will it not be religion to destroy all that are not of their profession? ... Religious freedom was the first inlet to all those confusions ... and destructive opinions that overspread this nation'. ${ }^{22}$ So in this text Locke blames religious pluralism for the violence and bloodshed in his era.

Within seven years, however, Locke completely reversed his position on toleration. In his 1667 Essay Concerning Toleration, his former plea for the magistrate's right to make religious impositions has disappeared. Instead, in his essay Locke addresses the topic of the limits to state authority. Now he sees the state's policy to enforce one religion over and at the cost of other ones as the main cause of religious violence. In addition, he no longer believes in the efficacy of the state's control over religious issues. His main postulate seems to be that the state should tolerate religious plurality (although, as we shall see in the next section, within limits). Five considerations underlying Locke's plea for religious toleration may be found in the works he wrote from 1667 onwards.

Locke's main argument for religious toleration flows from the distinction he makes between church and state. As he notes in the beginnings of his Letter Concerning Toleration (1689):

\footnotetext{
Locke (1689a), above n. 14, at 9.

Id., at 9 .

Locke (1660), above n. 16, at 171.
} 
I esteem it above all things necessary to distinguish exactly the business of civil government from that of religion and to settle the just bounds that lie between the one and the other. If this be not done, there can be no end put to controversies that will be always arising .... .23

The concern of the church is the salvation of souls, whereas the concern of the state is a secular one. It consists of the preservation and protection of civil goods: life, liberty and estate. To Locke - and in contrast to what was proclaimed by contemporary Catholic rulers such as James II in England and Louis XIV in France - the magistrate can have no authority over man's souls, for instance, by imposing one kind of religious worship or by forbidding others. Civil authorities have no jurisdiction over matters of religion. Only when someone's religious commitment constitutes a direct threat to the public peace and order, civil authorities may legitimately restrict religious freedoms.

From this first consideration flows a second one, which addresses the need for freedom of conscience. Rather than having a duty to take part in a forced unity of outward conformity, any individual should take care of the salvation of his own soul. This view betrays a rather individualistic - and one may even say 'privatised' - view of religion. Locke: ' ... these are things between God and me. Kneeling or sitting in the sacrament can in itself tend no more to the disturbance of the government or injury of my neighbour than sitting or standing at my own table' ${ }^{24}$

A third consideration concerns the non-enforceability of belief. In his own words, 'I cannot be saved by a religion that I distrust and by a worship that I abhor' ${ }^{25}$ Notice that this reasoning also flows from Locke's core distinction between statist and secular affairs - based on outward force - and ecclesiastical and spiritual matters, resting on inward convictions. One's belief can never be influenced by threats or by coercion. In the words of Church Father Augustine, 'Credere not potest homo nisi volens'. Translated: 'Man cannot believe against his will'.

A fourth and prudential argument that Locke brings forward is that a forced religious unity does not work, since it is likely to produce disunity. To Locke, peaceful union among Protestants is to be achieved by gentleness and charity rather than by the imposition of uniformity. ${ }^{26}$ The ideal of (Christian) religious pluralism seems to underlie all his works from 1667 onwards.

Finally, in Locke's texts one may also find a typical Christian argument for religious toleration. Christianity as such requires toleration, for, as Locke writes, 'toleration (is) the chief characteristical mark of the true church'. ${ }^{27}$ With regard to the topic of religious toleration, I think it is safe to say that Locke's core business has always been a defence of 'mutua inter Christianos tolerantia', that is, of mutual toleration among Christians.

\subsection{The Limits of Toleration}

Among constitutional scholars Locke is generally known as one of the early and most ardent defenders of religious toleration. No doubt, in comparison with most of his contemporaries, his later view of toleration as a positive value was quite revolutionary. In $17^{\text {th }}$-century Western Europe, toleration was still drawn in bleak lines. ${ }^{28}$ Most people in that era found the idea of toleration quite intolerable. At best, it could provide a provisional solution to permanent religious wars. At worst it was viewed as a dangerous licence and as a risk to the salvation of the soul.

Seen from a modern perspective, however, one cannot but be struck by the limits that Locke sets with respect to toleration. According to him, both Catholics and atheists should not be tolerated. They both pose a danger to the state. With regard to Catholics,

Locke (1689b), above n. 15, at 26.

24 Locke (1667), above n. 18, at 176-177.

5 Locke (1689b), above n. 15, at 38.

6 R. Woolhouse, Locke. A Biography (2007), at 167.

7 Locke (1689b), above n. 15, at 23.

28 See, e.g. H. Oberman, 'The Travail of Tolerance: Containing Chaos in Early Modern Europe', in O.P. Grell and B. Scribner (eds.), Tolerance and Intolerance in the European Reformation (1996), at 13-31. 
Locke notes that their opinions are destructive to all governments except the Pope's. The magistrate is not obliged to protect churches that claim an authority that can be said to endanger the security of the state and foment civil strife. Locke also uses the argument of double loyalty. Most Catholics express a blind obedience to the Pope who would allow them to dispense with all their oaths, promises and obligations. A final argument he raises concerns the need for reciprocity. Toleration should not be extended to those who are themselves unwilling to practise it themselves. Surely, he must have had in mind here the 1685 revocation of the Edict of Nantes - the toleration pact with the Huguenots in France - by Louis XIV.

Locke also categorically denies atheists any toleration. To him, the belief in God is the foundation of all morality. In his own words, 'The taking away of God ... dissolves all' ${ }^{29}$ This consideration is quite understandable in view of the elaborated primacy of the natural law as the foundation of a well-ordered society. Someone who does not believe in God cannot be bounded by God-given moral precepts. Such a man would be a noxious and dangerous beast, incapable of society. As Locke writes in another text, 'The origin and foundation of all law is dependency. ... If man were independent, he could have no law but his own will, no end but himself. He would be God to himself' ${ }^{30}$ Locke did not think society could be erected on such a libertine basis.

We may well conclude now that Locke offers us an explicitly Christian - and more precisely, Protestant - defence of religious toleration rather than a secular one. As Dunn ${ }^{31}$ notes, to Locke religious freedom means the freedom (of Christians) to be religious in their own way. It does not include the freedom (e.g. of an atheist) to be totally indifferent to religious considerations. From our $21^{\text {st }}$ century perspective, this may sound too petty and narrow-minded to be convincing any longer. In view of Locke's proposition on the primacy of the natural law, it is quite consistent, however.

\subsection{Limited State Authority}

Let us round up our exposé of Locke by sketching Locke's answer to the second question on the role of the state with regard to religious matters. On the basis of the foregoing, it will come as no surprise that to Locke the state should play a quite limited role. The state should abstain from any intervention in the religious sphere. To him, statist intervention into religious debates is principally problematic.

Three kinds of considerations may be found in Locke's work. The first two have already been touched upon in Section 4.3. First of all, it is undesirable, since church and state each have their own competences. In addition, it is impossible since religious convictions can never be enforced by civil actors. What is more, Locke considered such intervention as unnecessary, due to his quite optimistic and positive view of man. According to him, most citizens are naturally inclined to follow natural law maxims. This view of man is accompanied by an equally optimistic (and 'privatised') view of Christian religions. Choosing a religion and living by its rules is a private issue, something between the individual believer and the God he worships. Not only the state's part, but also the church's part seems to be played out here. In Locke's Protestant view, the church does not have a special privilege to religious truth. It is just an association of believers.

9 Locke (1689b), above n. 15, at 51.

30 J. Locke, Political Essays, at 328-329, in P. Milton, 'Religious Toleration', in D.M. Clarke and

C. Wilson (eds.), The Oxford Handbook of Philosophy in Early Modern Europe (2011), at 571-590.

31 J. Dunn, Locke (1984), at 25. 


\section{Pierre Bayle (1647-1706)}

\subsection{Context}

Locke's conviction that atheism undermines the foundation of morality would have been accepted by almost all his contemporaries, but it was not shared by Bayle. In this section, I will give an overview of Bayle's main postulates on religious toleration and on the role of the state. First, however, let me briefly sketch the context of Bayle's writings.

Pierre Bayle was born in 1647 in a Huguenot family in the south of France near the Pyrenees. The Huguenots were a Protestant minority denomination comprising about $5 \%$ of the French population. During his twenties, Bayle reconverted to Catholicism, but after a year he retraced his steps towards Protestantism. The Huguenots in France have always experienced periods of persecution and exile, alternating with periods of tolerance. The Edict of Nantes, promulgated in 1598 by Henry IV, had granted them locally based privileges in the form of some freedom of conscience and of worship. During the reign of Louis XIV (1643-1715) religious - that is Catholic - unity became a predominant state policy again. This policy was expressed in the slogan: 'Une foi, un loi et un roi'. That is, 'one belief, one law and one king'. In his coronation oath the Sun-King had promised to put down all blasphemies and combat all heresies in order to achieve religious and political unity of the French state. He saw this as his mission in believing himself to be 'the most Christian king'. Consequently, from the middle of the $17^{\text {th }}$ century the Huguenots fell victim to rapidly increasing intolerance and persecution, resulting in the revocation of the Edict of Nantes in 1685. During the eighties, a lot of Huguenots - and, among them, Pierre Bayle - took refuge in the Dutch Republic, especially in Amsterdam and Rotterdam. In the midst of a rigid Calvinist state policy, these cities were known for their liberal and tolerant policy, their so-called gedoogbeleid. ${ }^{32}$ In 1681, Bayle arrived in Rotterdam and took up residence in the French-speaking enclave. In 1706, he died in Rotterdam.

'Le philosophe de Rotterdam' - as Bayle is commonly called - wrote all his works during his refuge in Rotterdam. His main works are, in chronological order, Pensées diverses sur la comète (1682); ${ }^{33}$ Critique générale de l'histoire du Calvinism (1683); ${ }^{34} \mathrm{a}$ monthly periodical, called Nouvelles de la république des lettres (from 1684 onwards), ${ }^{35}$ Nouvelles lettres critiques sur 1'histoire du Calvinisme (1685); ${ }^{36}$ Commentaire philosophique $(1686)^{37}$ and his Dictionnaire historique et critique (1696) ${ }^{38}$ In all these works, his personal experiences as a member of a persecuted religious minority can be easily traced. They can all be read as critiques on the one-religion policy conducted by Louis XIV.

\subsection{Toleration to the Max}

Bayle's main contribution to legal and political philosophy has indubitably been his ardent defence of an unrestricted and unqualified toleration of belief for everyone. In contrast to Locke, Bayle addresses the need for toleration to the max, stretching towards non-Christians, Catholics and atheists as well. What are his underlying considerations?

\footnotetext{
32 See on this topic W. van Bunge, 'The Presence of Bayle in the Dutch Republic', in W. van Bunge and H. Bots (eds.), Pierre Bayle (1647-1706), Le philosophe de Rotterdam: Philosophy, Religion and Reception (2008), at 197-216.

33 P. Bayle, Pensées diverses sur la comète (1682). In Oeuvres diverses II. I have used the Dutch translation by M. Wielema, De inslag van een komeet. Beschouwingen over geloof, ongeloof en bijgeloof (2006).

34 P. Bayle, Critique générale de l'histoire du Calvinism (1683). In Oeuvres diverses I.

35 P. Bayle, Nouvelles de la république des lettres (1684). In Oeuvres diverses III.

36 P. Bayle, Nouvelles lettres critiques sur l'histoire du Calvinisme (1685), In Oeuvres diverses II.

37 P. Bayle, Commentaire philosophique (sur ces paroles de Jésus-Christ: Contrain-les d'entrer) (1686). In Oeuvres diverses $V$. I have used the English translation: Pierre Bayle's Philosophical Commentary. A Modern Translation and Critical Interpretation, A. Godman Tannenbaum (ed.) (1987).

38 P. Bayle, Dictionaire historique et critique (1696). In Oeuvres diverses VII.
} 
His own history as a refugee offered Bayle a first, pragmatic argument for religious toleration. As he had experienced himself, a policy of religious intolerance does not create religious unity. Rather, it produces disorder and chaos. For Bayle, there were also three principled considerations why religious toleration should be maximal.

Bayle's main principled argument followed from his skepticism, splitting up faith and reason. Reason alone could not lead humans to truth, unless it was supplemented by faith. This epistemological assumption on the limits of rationality was derived from Bayle's reading of Montaigne. According to Bayle, it could not be proved by rational arguments which religious doctrine was true and which one was false or whether there was one true religion. Hence, one could not distinguish orthodoxy from heresy. In view of this uncertainty and in anticipation of Judgment Day, we can not but respect any belief. For if one religious denomination would have the right to persecute another group, that other group would have the same right too.

From this consideration follows a second one. This is the importance Bayle attached to an unconditional freedom of conscience for everybody, including those whom everyone thinks utterly mistaken in their beliefs. To Bayle, everyone had the right to err and to find the right path again. No doubt, here, he had his own provisional reconversion to Catholicism in mind. Conscience, whether true or errant, always obliges. This postulate is commonly known as the so-called conscience errante-doctrine. In Bayle's day, it was quite a revolutionary assumption. Not only true (Christian) consciences, but also erring ones should be respected to the max. Everybody had the duty to obey his conscience, since it was viewed as the voice of God. It should be noted that this granting of a maximised freedom of conscience to individuals was not defined in rights terms. Just like Locke, Bayle argued that this freedom follows directly from our duties towards God.

A third rationale behind Bayle's plea for religious toleration was his disentanglement of religion and morality. ${ }^{39}$ To him, a belief was neither a necessary nor a sufficient condition for good behaviour. Bayle started his psychological and empirical investigations within the context of the Dutch Republic. As he noted, a lot of divergent religious denominations were living together. But, as he observed, at the same time the similarities between different types of human conduct were striking. From a $21^{\text {st }}$ century perspective, one cannot but be struck by Bayle's quite modern observations on human nature. His hypothesis was that our conduct is not determined by principles or by religious convictions, but by passions, impulses and temperament. This implies that from the point of view of public order it, is not at all relevant to which religion citizens adhere. Sincere and orthodox Christians may indulge in monstrous licentiousness and wickedness, whereas atheists may lead an honest life. In Bayle's books, King David (from the Old Testament) and Spinoza play these respective roles of 'vicious Christian' and 'righteous atheist'. ${ }^{40}$

This third consideration implies that to Bayle only one's behaviour - and not one's religious conviction - should fall under the jurisdiction of the law. That is, religious beliefs should not be a matter of legislation regulated by the state. In the words of Godman Tannenbaum, an expert on Bayle: ${ }^{41}$ 'Whether they be papists in Protestant states or Protestants in Catholic states, to keep people chained up like animals or to deprive them of rights of citizenship ... is wrong. Bayle would protect minorities from efforts to block their free exercise of religious rites'. So it is not the task of a state to enforce one dominant religion at the cost of others. Apart from the fact that statist intervention into religious affairs would exceed the powers of civil authority, it is also quite useless since our conduct is not determined by our belief.

In view of the foregoing, we may well conclude that in his works Bayle does not address the topic of religious toleration. He addresses the need for civil toleration, 'the right of all religions, both heretical and orthodox, to remain separate and distinct from one another within the secular framework of the state' ${ }^{42}$

39 Bayle (1682), above n. 33.

40 See his article on 'David' and 'Spinoza' in his Dictionaire (1696).

41 Godman Tannenbaum (1987), above n. 37, at 255.

42 W. Rex, Essays on Pierre Bayle and Religious Controversy (1965), at 79. 


\subsection{No Toleration for Intolerants}

To Bayle, toleration should be extended not only to all Christian denominations, but also to Jews, Muslims, atheists and heretics. They all have the right to freely exercise their religion. But are there no limits whatsoever to toleration? This question should be answered in the negative. There definitely is a limit to toleration in Bayle's doctrine. This limit may be illuminated by the well-known phrase that is commonly attributed to him: 'Il faut tolérer tout le monde, sauf les intolérants'. That is, we should tolerate anybody, except the intolerants.

This quote - lucid as it might seem at first sight - is at the same time rather blurry. For who exactly are these intolerants that should not be tolerated? First, it will have become clear by now that Bayle's scope will be on intolerant actions rather than intolerant beliefs. For one, according to him, any orthodox belief will always be intrinsically intolerant towards other-believers and nonbelievers. Moreover, as we saw before, we should distinguish religion from behaviour. It is no use dwelling on intolerant religions, since these religions do not determine their believers' behaviour at all. So anyone can stick to his own religion, orthodox and liberal denominations alike. According to Bayle, there is only one precondition that should be met. One should not act intolerably towards otherbelievers and nonbelievers. By doing so, one forfeits one's right to a tolerant treatment oneself. Surely, Bayle must have had in mind here fanatical religious denominations committing discriminatory and exclusionary acts, such as the Catholics in France or Orthodox Calvinists in the Republic. Both groups believed that they alone possessed the truth and both agreed on persecution of heretics and atheists.

In conclusion, Bayle's postulate on the limits of toleration introduces the norm of reciprocity. For Bayle - as for Locke - toleration has to be reciprocal. It should not be extended to those who are unwilling to practise it themselves.

\subsection{The State as a Secular Equilibrist}

The last topic concerns the role of the state with regard to religious matters. Both Locke and Bayle argued against religious (in their context, primarily, Catholic) intolerance. Both presupposed a separation of the civil and the religious realm, whereby the monarch would be stripped of his sacrosanct position. ${ }^{43}$ The king should no longer be the defender of the one true faith. He is just a secular authority.

There are some differences on this topic as well, however. In Bayle's view it was not enough that the state should refrain from entering into religious debates and leave these to the believers. On the contrary, in Bayle's view civil authorities should play a pivotal and active role within these debates. His plea for toleration to the max went hand in hand with an equally maximised role of the state. A second distinction is that Locke sticks to a strict separation between church and state, thereby presuming an equal standing of the two actors, whereas Bayle introduces a hierarchy of the state over the church. Religions should always be controlled by civil authorities.

In my view, these two differences mainly originate from Locke's and Bayle's underlying views of humankind and religion. As we have already seen in Section 4.5, Locke's views on these topics were quite positive and optimistic. Most people will be led by their inner light, the natural law. We are at the height of Enlightenment optimism here. Let citizens stick to their religious values and practices and all will end up well. Reading Bayle, there is none of this optimism, however. With him, we are in the heyday of bleak Calvinist pessimism. According to Bayle, in everyday practice, people are not led by rational and moral maxims but by base passions, lusts and temper. Bayle's view of religion is equally pessimistic. The later Lockean plea for religious (Christian) pluralism is replaced by a rather gloomy picture of religion. Religion will always be a danger. This insight was indubitably based on Bayle's own experiences of persecution and exile. As a member of a small minority group, Bayle experienced first-hand that one should always be aware of the looming threat of a dominant religion. To him,

43 Godman Tannenbaum (1987), above n. 37, at 253. 
theological rivalries - and especially the lust for power by dominant religious groups - were the main threats to an orderly society. They could lead to permanent religious divisions and strife and they could even lead to persecution and elimination of heretics. Seen from this perspective, it is quite understandable that Bayle considered orthodoxreligious viewpoints much more harmful to society than atheist views.

On the basis of his view of man and religion, Bayle states that it is the main function of the state to provide order, security and civil peace. He is also critical of Locke's social contract view of government and defends a form of enlightened despotism. But, one may ask, what should be the exact role of the state with regard to religious matters? As we noticed before, to Bayle there is a lot that the state may no longer do. For example, it can no longer enforce one true religion at the cost of erring others by using force and violence. For Bayle the proper role of the state seems to be - in the words of the modern scholar Ian Buruma - 'to tame the Gods' ${ }^{44}$ That is, the state should block religious power. In the words of Israel, 'The role of law, government, media and policing in a society ... is precisely to make sure that no theological bloc of any description should be allowed to translate its biases and prejudices into active harassment, discrimination and violence' ${ }^{45}$ In yet other words, we may conclude that to Bayle the state should act as a secular equilibrist.

\section{Lessons from Locke and Bayle}

In this final section, I will investigate how to translate the insights gained from Locke (A); from Bayle (B) and from them together (C) to the current Dutch debate on constitutional rights. What lessons may be drawn? In my exposé, I will first assess Israel's stand on the two positions.

(A) Let us start with Israel's assessment of Locke's view. As noted before, Israel views Locke as one of the representatives of the so-called Moderate Enlightenment, a current that he vehemently attacks. To me, Israel's criticisms of Locke sound apodictic and too one-sided to be convincing. No doubt, there are some strikingly outdated and narrowminded elements in Locke's view of toleration. Take, for example, Locke's conviction that both Catholics and atheists should be excluded from any toleration policy. On the other hand, there are some merits of his approach, which still stand up to $21^{\text {st }}$ century standards. Among Dutch jurists, Locke is commonly seen - and I think rightly so - as one of the fathers of the liberal-democratic body of thought. He has provided us with the underpinnings of modern ideals such as the rule of law; limited government and natural, and inalienable rights of individuals. These ideals all derive from the revolutionary methodology Locke adopted in his philosophy. Rather than presenting a top-down model of political order, in Locke's social contract view any government should be legitimised by way of consent of the governed. This assumption still lies at the basis of any democratic political system.

Apart from these well-known merits, in my paper I have traced some other, less illuminated aspects of Locke's philosophy that might be useful to current debates on constitutional rights. These aspects can be formulated in two lessons. The first and main lesson seems to me that there are always moral limits to the exercise of one's natural or, as we would call them now, 'constitutional' - rights. Locke's view of natural rights has turned out to be built on the primacy of natural law, God-given moral precepts. That is, natural law maxims - such as the duty to preserve mankind and not to harm others - establish limits to the exercise of one's individual rights. This consideration may put into perspective both the axiomatic individual autonomy and the extensive and commonly rather absolute interpretation of fundamental rights in Dutch constitutional law. In contrast to what is suggested by Burkens in his treatise on constitutional law, it seems to me - and this is exactly what Locke would argue - that the way citizens make

44 I owe this phrase to the title of I. Buruma, Taming the Gods. Religion and Democracy on Three Continents (2010).

45 Israel (2005), above n. 1, at 15. 
use of their fundamental rights is not their own business. To make an appeal to one's rights always presupposes some moral responsibility towards others. Reformulated in legal terms, a rights bearer may not abuse his rights in order to merely pester his neighbour. ${ }^{46}$

The second lesson flows from Locke's separation doctrine of church and state. It can be formulated as follows: civil and statist authorities should not intervene in religious and ecclesiastical affairs, but also conversely, the church should stay away from politics. The attentive reader may have noticed, already, that the first half of the statement has already been laid down in Dutch constitutional law handbooks. It is exactly the elaborated doctrine of interpretative restraint. Within liberal states, individuals should have the freedom of worship and to exercise their religious practices. Only when a practice constitutes a threat to public order can civil authorities legitimately restrict religious freedoms. Seen from this Lockean perspective, the Dutch First Chamber last year made the right decision by rejecting the proposed bill on ritual slaughtering.

The second half of the separation doctrine has been relatively disregarded, though. The church has no authority with regard to political affairs. Church and state should have their own tasks. They should be aware of not crossing the boundaries between them. As we have seen before, Locke's underlying Protestant view of religion indubitably has privatised traits. Churches may not use secular power to pursue their spiritual ends. This second element of Locke's separation doctrine might be used in order to put question marks behind the current explicitly religious appeals in the Dutch public sphere by civil servants, having conscientious (Orthodox-Christian based) objections to same-sex marriages. It seems to me that these appeals cannot be defended by referring to Locke's philosophy.

(B) With regard to Bayle's views of religious toleration, let us start with Israel's stance on the matter. In Israel's work, Bayle is presented as the main hero of the Radical Enlightenment. Israel seems to assume that a theory that is radical in one aspect Bayle's view of toleration - will be all-round radical. With regard to Bayle's political theory, nothing is further from the truth, however. As we have seen, in comparison with Locke's democratic social contract view, Bayle's conception of politics tends to be quite traditional and conservative. Nowhere in Bayle's texts can one find references to natural and inalienable individual rights, to be guaranteed and enforced by a constitutional state. Instead, Bayle criticises social contract views of society as too revolutionary and emphasises the need for an autocratic political order. It goes without saying that this view of politics considerably reduces the usefulness of Bayle's approach to current Dutch debates on individual rights.

Notwithstanding these limitations, Bayle's theory may still have some merits to the current debate on these rights. Two lessons may be drawn. The first one is not to linger on religious identities. In Bayle's work we bear witness to a strikingly modern disentanglement of religion and behaviour. To him, it is no use dwelling on someone's religion, since a religion does not determine behaviour. Seen from this perspective, one may put some question marks behind any (religious) identity politics by civil authorities. Apart from the disadvantage of locking up individuals within their group identity ${ }^{47}$ in all likelihood Bayle would consider such a policy as unproductive. It would be better for civil authorities to focus on law-violating behaviour than to focus on errant or dangerous beliefs. This lesson seems to me quite relevant to the current Dutch debate on Islam. As Israel rightly suggests, 'Rediscover toleration and don't make such a fuss about Islam'. ${ }^{48}$

Bayle's second lesson addresses the role of the state. It may be formulated as follows: a policy of toleration requires an active and neutral state. On the basis of this presupposition, we may re-evaluate the currently dominant interpretation of the Dutch

\footnotetext{
46 See further M. Galenkamp, 'Misbruik van recht volgens Scholten, Eggens en Meijers', in Liber Amicorum René Foqué (2011), at 35-48.

47 M. Galenkamp, Individualism versus Collectivism. The Concept of Collective Rights (1993), at 159.

48 J. Israel, 'Herontdek de tolerantie en maak je niet zo druk om de Islam', NRC Handelsblad, 11 December 2004 , at 15 .
} 
doctrine on interpretative restraint by civil authorities. Bayle shares Locke's conviction that it is not the task of civil authorities to enforce one religion at the cost of others. Religious minorities should have the right to free exercise of their rites and practices. So even for Bayle there is a need for some interpretative restraint by the state with regard to these practices. But - and here Bayle departs from Locke's stance - this doctrine does not imply that the state should adopt a hands-off policy towards religions. Instead, it should play an active role. Civil authorities should watch over the societal equilibrium among the various religious denominations. They should make toleration work, guaranteeing and enforcing mutual respect. According to Bayle, if the state remains too detached and passive, dominant religions will take over and irrevocably commit atrocities towards other-believers and nonbelievers.

The state should not only play an active role, but also function as a neutralising actor. Here, we may counter a tendency within Dutch constitutional debates. As noted before, in the Netherlands the state is sometimes viewed as functioning as a positive facilitator of religions. ${ }^{49}$ The underlying consideration seems to be that small and weak religious denominations are in need of protection against and by the state. Bayle would definitely not agree on this. Instead, he would consider such a policy to be dangerous, since the interests of nonbelievers are likely to be overruled. The neutral state should be protected against religious perspectives. Thus, here Bayle turns out to be one of the protagonists avant la lettre of the French doctrine of laïcité.

(C) A final lesson that can be drawn from the works of both Locke and Bayle is the already elaborated need for reciprocity. Both thinkers argue that in order to be tolerated by others, one should tolerate others as well. No toleration for intolerants. To modern ears, this slogan may sound as a truism. Several $20^{\text {th }}$-century scholars have expressed this ideal too. Take, for example, Karl Popper in his classic work, The Open Society and Its Enemies: 'Unlimited tolerance must lead to the disappearance of tolerance. If we extend unlimited tolerance even to those who are intolerant, if we are not prepared to defend a tolerant society against the onslaught of the intolerant, then the tolerant will be destroyed, and tolerance with them' ${ }^{50}$ Strangely enough, however, nowhere in the Dutch doctrine of constitutional rights does one come across this precondition. I think that the inclusion of reciprocity - as a precondition for the legitimate exercise of one's fundamental rights - would really make a difference.

This norm raises a lot of new questions, however. ${ }^{51}$ What exactly do we mean by intolerance: intragroup, intergroup or external intolerance? Furthermore, how exactly should it be applied? For example, do we have to distinguish intolerant expressions from intolerant behaviour and can this neat distinction always be made? Finally, should the norm of reciprocity merely function as a governmental guideline or should it be better to see it as a norm for all citizens? No doubt, all these questions have to be elaborated upon in more detail. Let me make one final point. It seems to me that the norm should apply not only to civil and religious authorities, but also to citizens in their interpersonal relations. That is, if one appeals to a fundamental right, one should grant one's fellow citizens the same measure of rights protection too. It should be noted, that this is exactly Locke's natural law, stripped of its narrow-minded and Protestant-based underpinnings and reformulated in secular terms. Fundamental rights should be seen as a package deal. So-called selective shopping in the supermarket of constitutional rights is not to be allowed. To give an example, the classic appeal of the Dutch SGP on its right to freedom of religion and assembly does not sound that convincing in view of its exclusionary perspective on Islam and on women. Ultimately, we face the need for balancing again. This is a guideline to be applied not only by civil authorities, but also by citizens themselves. As Locke and Bayle may teach us, if you ask for toleration, please practise it yourself.

\footnotetext{
See above n. 13

50 K. Popper, The Open Society and Its Enemies, Vol. I: The Spell of Plato (1945), ch. 7, note 4.

51 I thank Marjolein van den Brink (University of Utrecht) for raising these fundamental issues (personal correspondence).
} 